\title{
Intrusive events at Kvanefjeld in the Ilímaussaq igneous complex
}

\author{
BJARNE LETH NIELSEN AND AGNETE STEENFELT
}

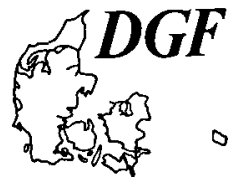

\begin{abstract}
Nielsen, B. L. \& Steenfelt, A.: Intrusive events at Kvanefjeld in the Ilimaussaq igneous complex, Bull. Geol. Soc. Denmark, vol. 27, pp. 143-155, Copenhagen, March 23rd, 1979. https://doi.org/10.37570/bgsd-1978-27-13

The geology of the Kvanefjeld region in the Ilimaussaq intrusive complex is reviewed with special empha-sis on intrusive mechanism and on the spatial distribution of rock units before the intrusion of the lujavrite. The lujavrite was emplaced by permissive intrusion, and subsidence of blocks of the older rocks derived from the roof of supracrustals, gabbro, and from the earlier syenites of llimaussaq, took place extensively. It is argued that the present level of erosion in the Kvanefjeld area is about $300 \mathrm{~m}$ below the roof of the intrusion. The early augite syenite and alkali syenite in the southern and central part of Kvanefjeld are believed to be close to their original position as a large raft in the naujaite. The northern limit of the augite syenite intrusion was probably close to the present limit of the augite syenite.

The origin of the marginal deformation zones in the country rock xenoliths is discussed and it is proposed that the deformed zones represent early shear zones and joints which were heated and metaso-matically altered before the intrusion of the lujavrite. The ultimate shearing and deformation occurred during the collapse of the roof when the bulk of the lujavrite was intruded.
\end{abstract}

Bjarne Leth Nielsen and Agnete Steenfelt, The Geological Survey of Greenland, Øster Voldgade 10, DK-1350 Copenhagen K, Denmark. September 5th, 1978.

Contribution to the Mineralogy of Ilímaussaq, No. 55 .

The Kvanefjeld area of the Ilimaussaq igneous complex in south-west Greenland has been studied in great detail because of its extensive uranium mineralisation which constitutes a potential uranium ore (Sørensen et al. 1969, Sørensen et al. 1974).

The uranium is associated with lujavrite, a mafic nepheline-analcime syenite that was emplaced as the final intrusive event of the complex. The lujavrite encloses abundant bodies of country rocks and earlier formed syenites and nepheline syenites, and the area has been described as a huge intrusion breccia (Sørensen et al. 1974). However a more specific discussion of the history of formation of the Kvanefjeld area has not been put forward hitherto.

The results of field work and geochemical research in the Ilimaussaq complex carried out during recent years, as well as the information provided by a drilling programme for uranium in the northern part of Kvanefjeld in 1977 (Nyegaard et al. 1977) have added much to the understanding of the formation of the complex geology of the area. Based on this new information the present paper concerns a description of the rock types at Kvanefjeld with special reference to features providing information on pre-lujavritic rock relations.

Some of the xenolith types in the lujavrite have been deformed along their margins whereas other xenoliths are angular blocks without any deformation. Such features are important to the establishment of the sequence of events and will be discussed together with the mechanism of magma intrusions at Kvanefjeld.

\section{Geological setting}

Kvanefjeld is situated at the north-western border of the Ilimaussaq igneous complex, which belongs to the Gardar igneous province of South Greenland (Emeleus \& Upton 1976). The complex was emplaced at $1168 \pm 21$ m.y. (Blaxland et al. 1976) into eroded basement granites of the Ketilidian mobile belt (1800-1750 m.y.; van Breemen et al. 1971) overlain by a succession of supracrustal lavas and sandstones of the Eriksfjord Formation (Poulsen 1964, Stewart 1964, J. G. Larsen 1977).

The Ilimaussaq complex (fig. 1) comprises a series of alkaline to peralkaline syenites and gra- 


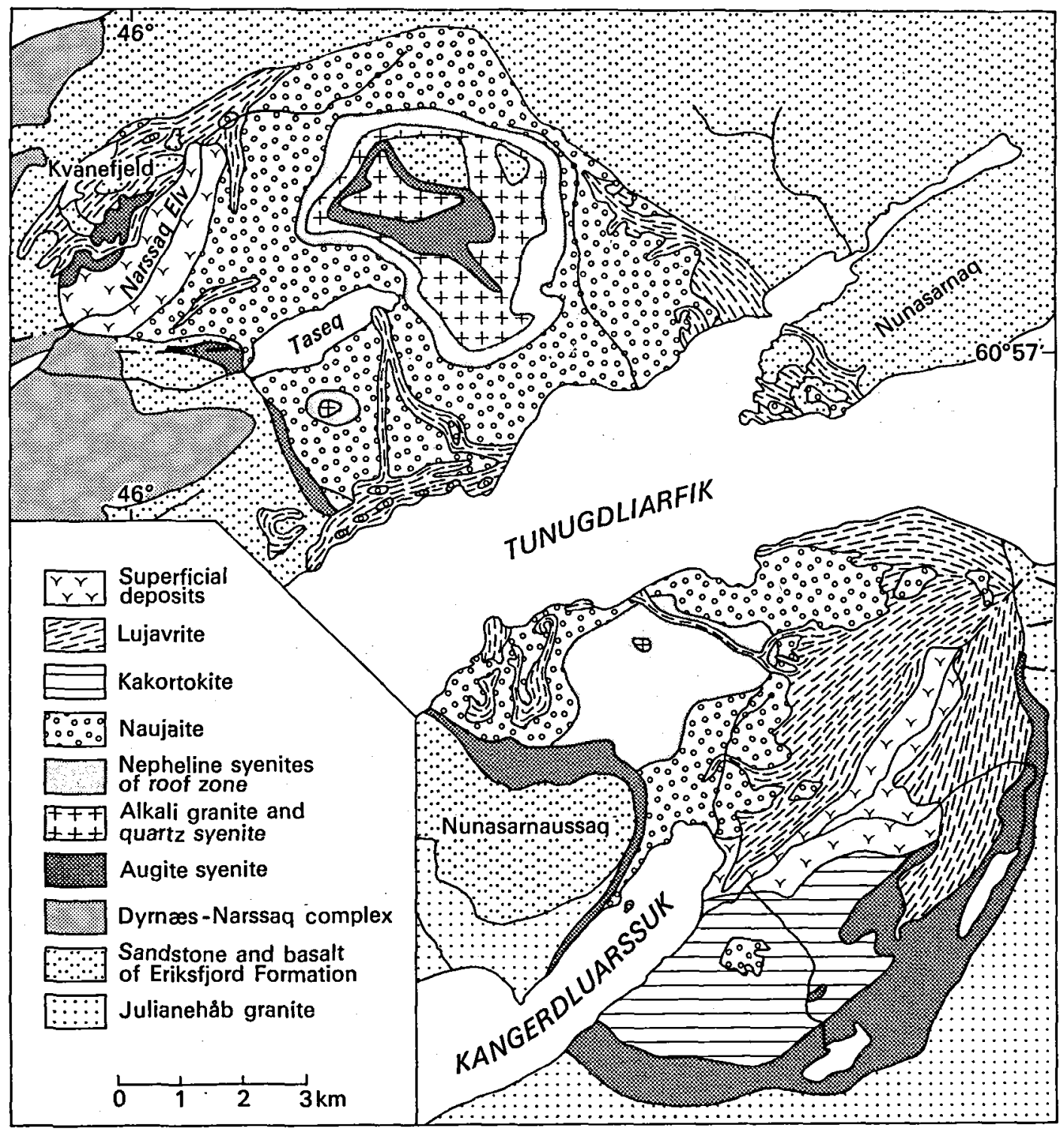

Fig. 1. Simplified geological map of the llimaussaq intrusive complex. After Ferguson (1964).

nite. Comprehensive descriptions of the geology and petrology are given by Ussing (1912), Sørensen (1958) and Ferguson (1964, 1970a). Different opinions have been expressed concerning the number and order of intrusive events involved in the formation of the complex as summarised by Sørensen (1970). The order and extent of the principal intrusive phases outlined in fig. 2 is based on Steenfelt (1972) and Blaxland et al. (1976), and is largely in agreement with Sørensen
(1970), L. M. Larsen (1976), and Sørensen (1978).

The augite syenite of phase I occurs along the southern and western margin, and as a sheet in a part of the roof zone left by erosion in the northern half of the complex.

Quartz syenite and alkali granite were formed from an alkali acid magma of phase II, the extent of which can only be inferred from the present remnants (see fig. 1). 


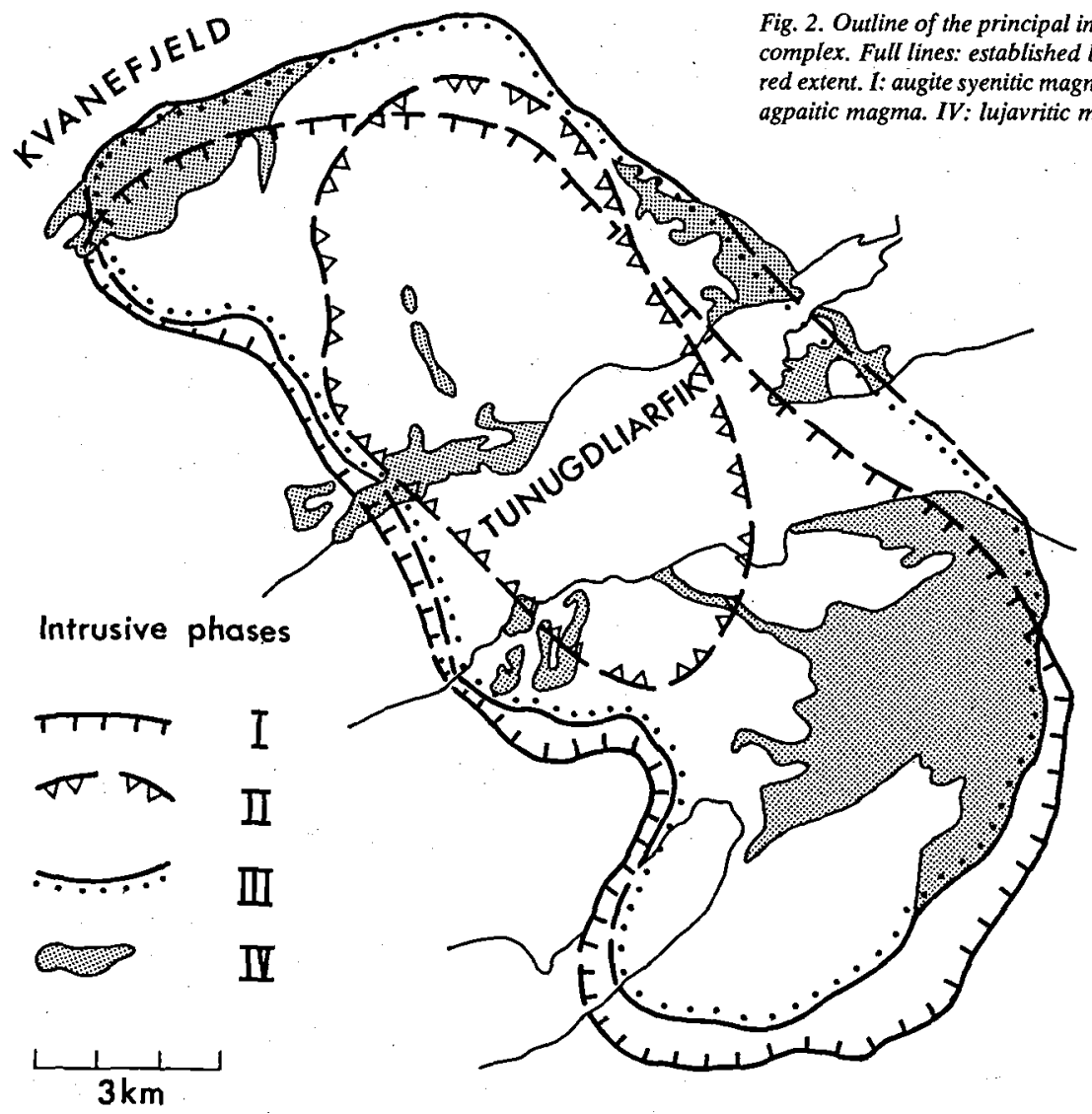

The agpaitic magma of phase III took up a large volume and crystallised during differentiation along an agpaitic trend to form a stratified sequence of syenites. Pulaskite, foyaite, sodalite foyaite, and naujaite (sodalite-nepheline syenite) were formed by downwards crystallisation from the roof, and kakortokite (eudialyte-nepheline syenite with a spectacular rhythmic layering) was built on the floor by crystal settling. The bottom of the magma chamber is below the level of exposure. The exposed part of the kakortokite was probably formed after the consolidation of the naujaite (Steenfelt \& Bohse 1975, Larsen 1976). Upwards the kakortokite gradually changes into a laminated lujavrite.

According to most authors the lujavritic magma was generated as the end product of the crystallisation and differentiation processes in the agpaitic magma. The lujavritic magma was situated between kakortokite and naujaite from where it finally intruded the overlying consolidated syenites as well as the surrounding country rocks, thus constituting the intrusive phase IV of fig. 2.

At Kvanefjeld as well as at other places in Ilimaussaq there is evidence for repeated injections of lujavritic magma with short time intervals.

\section{Geology of Kvanefjeld}

The geology of Kvanefjeld is shown in a simplified map (fig. 3). The area is bounded towards the north by lavas of the Eriksfjord Formation and towards the south and south-east by the valley of Narssaq Elv. The amount of outcrop is about $50 \%$ but outcrops are evenly distributed so that the inferred structures are reasonably well controlled. For the sake of simplicity many small-sized inclusions have been omitted and closely spaced inclusions are represented as coherent. The real amount of lujavrite at the surface is estimated at 30 to $40 \%$. 


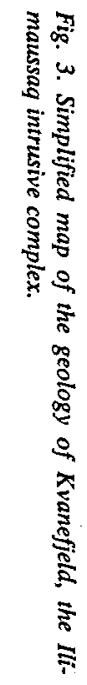

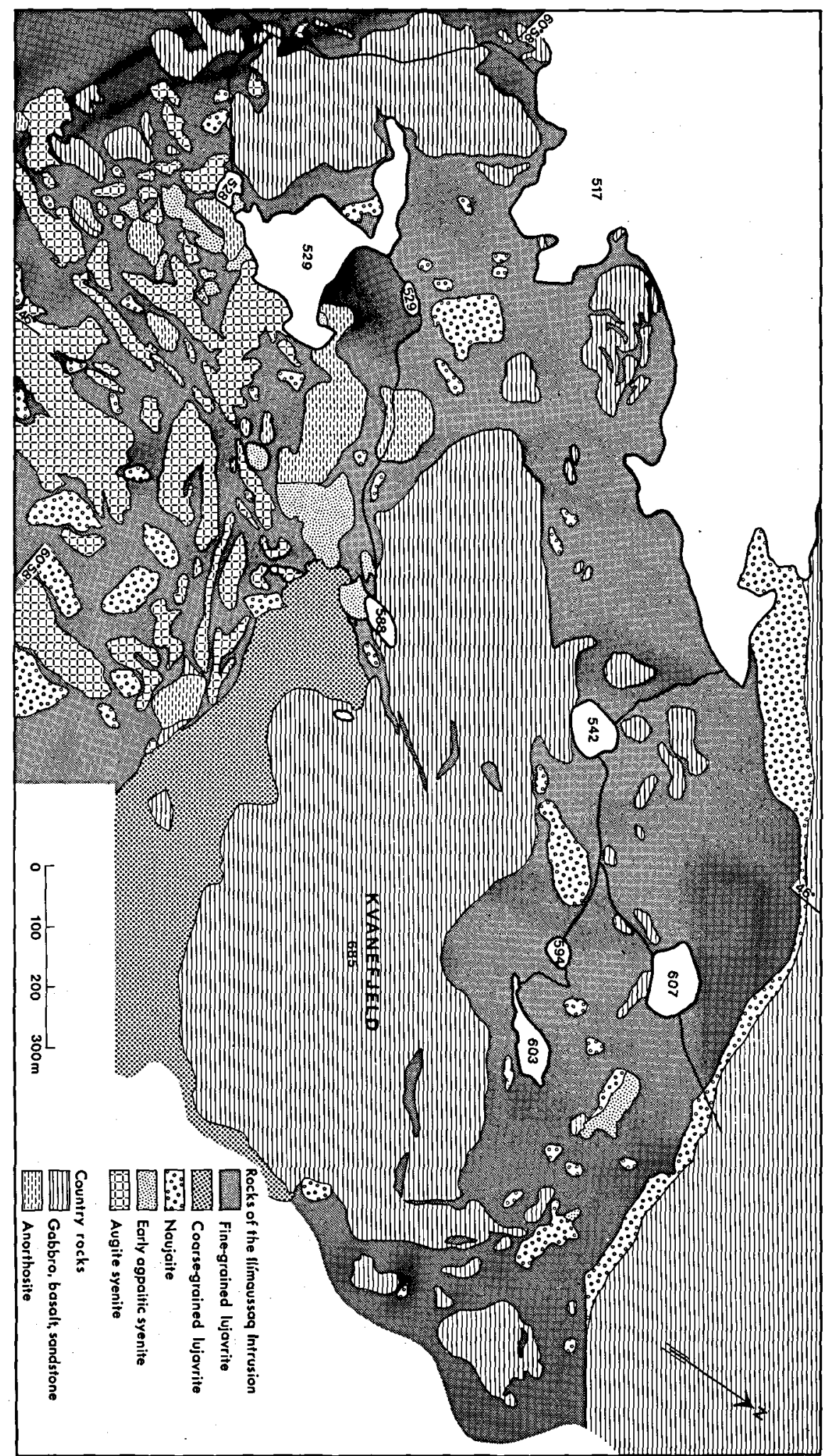


Lujavrite. The lujavrite is generally dark and fine-grained with a pronounced flow structure. At Kvanefjeld there are several types of lujavrite, which have been termed according to the predominant dark mineral (Sørensen et al. 1969). The following types are the most important: black arfvedsonite lujavrite, green aegirine lujavrite, black naujakasite lujavrite and brown acmite lujavrite. The field relations and the slightly different chemical composition of the types indicate that consecutive injections of lujavritic magma have taken place.

In addition to the fine-grained lujavrite a medium- to coarse-grained or pegmatic lujavrite is found in the central part of Kvanefjeld (fig. 3). This rock represents the youngest lujavrite intrusion of the area.

The lujavrites occur in large continuous masses with only few xenoliths in the northern and western part of Kvanefjeld, and enclose a large amount of xenoliths in the southern and central part. Drillings up to $400 \mathrm{~m}$ deep have confirmed that this pattern is continued at depth. The size of the xenoliths varies from more than 100 metres across down to a few square centimetres, and their shape is angular to rounded (fig. 4).

The lujavrites enclose and intrude all the other rock types in the area. The characteristic flow lamination displayed by the fine-grained lujavrites always conforms to the shape of the enclosed blocks, and it is developed in tiny veins as well as in more extensive masses. These features indicate that the lujavritic magma had a very low viscosity.

The lujavrites represent a cumulus phase in the lujavritic magma (Ferguson 1964, 1970, Engell 1973) and were probably emplaced as a crystal mush. The liquid phase of the lujavritic magma was very rich in alkalis, volatiles (including wa-

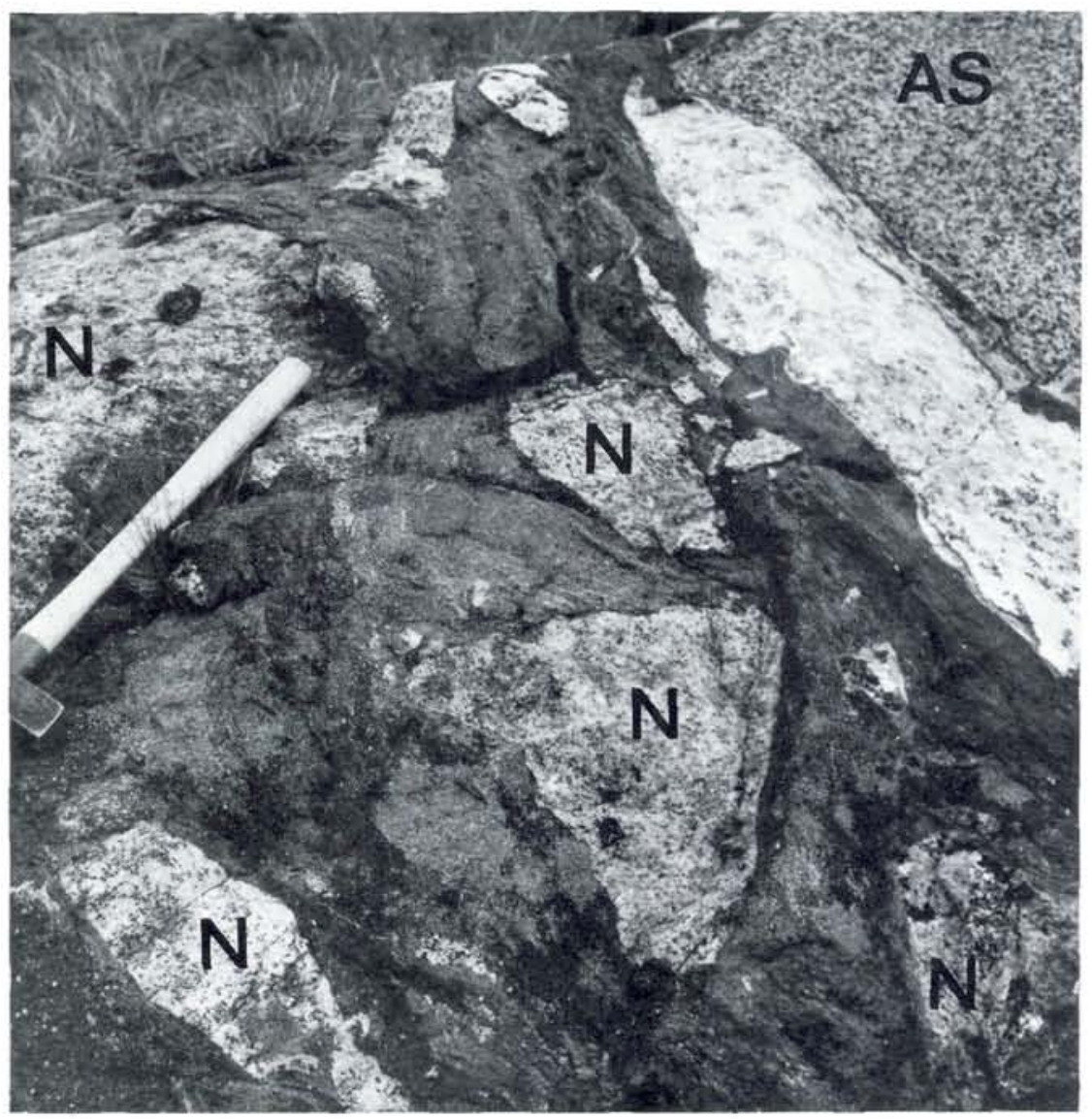

Fig. 4. Angular xenoliths of augite syenite (AS) and naujaite (N) in lujavrite, the central part of Kvanefjeld. The light coloured xenolith is albitised naujaite. 
ter), and incompatible elements, and a substantial part of this phase possibly escaped during the ascent of the magma as argued by Engell (1973). Owing to its high volatile content the liquidus temperature of the lujavritic magma was low (about $750^{\circ} \mathrm{C}$ at 1000 bars $\mathrm{P}_{\mathrm{H}^{2} \mathrm{O}}$ (Sood \& Edgar 1979)).

Xenoliths in the lujavrite

Basalts, sandstone, gabbro. Inclusions of country rocks from the wall and the roof of the magmatic complex are ubiquitous in the Kvanefjeld area. A few very large occurrences, one of which forms the summit of Kvanefjeld, (fig. 3) and many small angular to rounded fragments are seen on the surface. The drill cores have indicated the occurrence of large flakes and numerous small blocks of basalt enclosed in lujavrite, and some lava fragments are noted to occur embedded in naujaite, or bounded on one side by naujaite.

The supracrustal sequence represented by the xenoliths is dominated by basaltic lava flows interbedded with sandstone and conglomerate. The series is intruded by two prominent gabbro sills and by porphyritic dykes (Sørensen et al. 1969, J. G. Larsen 1974). Most of the small inclusions are fragments of lava while the two largest occurrences of country rock each comprise about 100 $m$ of a subhorisontally layered series of lavas and sediments. The gabbro constitutes a substantial part of the surface of the body of country rocks around the summit of Kvanefjeld. This body is cut by a NE-SW fault displacing the southern part about $100 \mathrm{~m}$ downwards (J. G. Larsen 1974).

The volcanic sequences represented in the xenoliths can not be correlated with the sequences found north-west of Kvanefjeld, and they are presumably derived from a higher level (J. G. Larsen 1974). Correlation of the gabbro with gabbros outside the Ilímaussaq complex also indicates that the Kvanefjeld gabbro has been displaced downwards in the order of $300-400 \mathrm{~m}$.

In general small xenoliths of lava display no textural changes at the contact with lujavrite. The volcanic rocks and gabbro of the large blocks, on the contrary, are bounded by zones of deformation often more than $10 \mathrm{~m}$ wide (described by Sørensen et al. 1969) that are veined by lujavrite and in which intense alteration has taken place. Mechanical deformation in these zones has re- sulted in pronounced stretching and weak to strong foliation, and chemically the zones were heavily altered by impregnation from the lujavritic magma. Conspicuous niobium minerals were formed in addition to sodium rich minerals like albite, analcite, natrolite, aegirine and acmite. Impregnation of this kind is largely confined to the zones of deformation. They trend preferentially NE-SW and seem to have been initiated by shearing movements.

Anorthosite. Anorthosite and gabbro-anorthosite are found as xenoliths in alkali syenite only in the southern and western part of Kvanefjeld. The anorthosite bodies are up to $100 \mathrm{~m}$ in diameter. Structurally they vary from granular or laminated to gabbroic block breccias (Nielsen 1968), and a complex history of formation is obvious. Most commonly the anorthosite shows a magmatic accumulation structure with euhedral plagioclase crystals in a gabbroic matrix. The intergranular matrix may occasionally intrude the settled crystals in veins that are several metres long.

Outside Kvanefjeld anorthosite has been found in alkali syenite in the valley of Narssaq Elv (fig. $1)$, and in augite syenite close to the south-eastern margin of the Ilimaussaq complex. Inclusions of anorthosite are widespread in the Gardar province e.g. at Tugtutôq and around Narssaq, and their origin has been discussed by Bridgwater \& Harry (1968), Upton (1971), and Patchett et al. (1976). A few anorthosite inclusions occur in the basalts and gabbros immediately north of Kvanefjeld.

The Kvanefjeld anorthosite shows many petrological similarities with anorthosite elsewhere in the Gardar province, and their origin is on the whole believed to be identical. Fractionation of plagioclase crystals in a parental magma of the igneous province has been considered by most authors to have played an important rôle.

Although the anorthosite xenoliths accompanied the alkali syenite at the time of its emplacement they are rarely in direct contact with the host rock. Lujavrite has intruded the contact zones and surrounded the anorthosite bodies in $5-50 \mathrm{~cm}$ wide zones. A unique character of the Kvanefjeld anorthosite, not reported from other places in the Gardar province, is the plastically deformed zones along the margins of the xenoliths (fig. 5). These zones are heavily chemically 


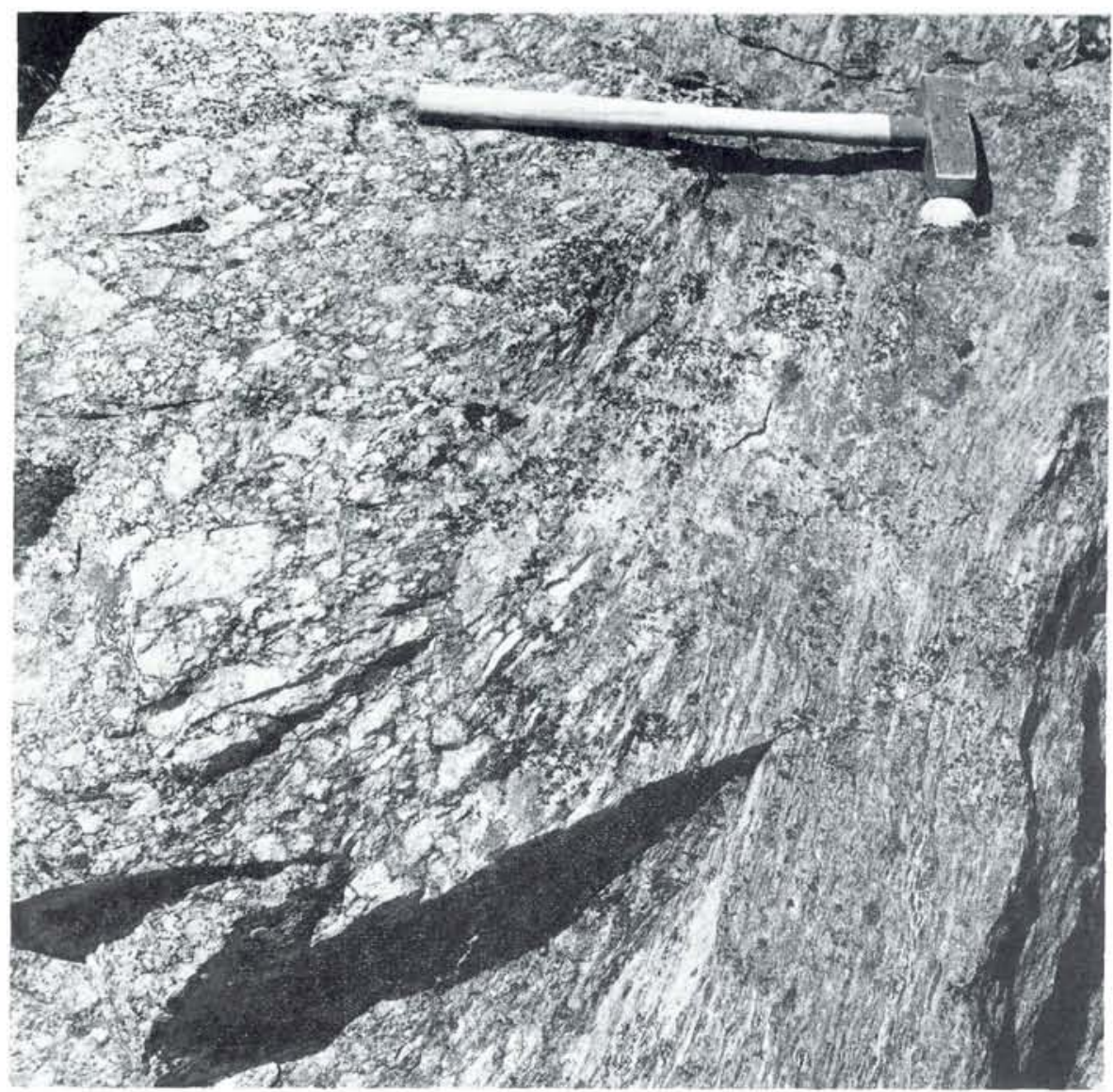

Fig. 5. Detail of an anorthosite xenolith with plastically deformed margin, the south-western part of Kvanefjeld.

altered and niobium mineralised (Hansen 1968) like most of the deformed margins of the gabbro and basalt xenoliths.

Augite syenite. The augite syenite is coarse-grained, grey, often rusty, and has a massive texture. Xenoliths of augite syenite are confined to the south-western part of Kvanefjeld where they occur mainly as closely spaced blocks. The situation of the xenoliths and the identical orientation of structures found in some adjacent xenoliths (Andersen, personal communication) suggests that the augite syenite once constituted one or very few large bodies now veined and enclosed by lujavrite.

Augite syenite is found as veins in the roof rocks and it is itself intruded by alkali syenite.

The belt of augite syenite is very likely a continuation of the augite syenite which occurs along the western contact between country rocks and naujaite north of Tunugdliarfik (fig. 2).

Alkali syenite. The alkali syenite is fine - to medium-grained with a bluish grey or greenish grey appearance. Its mineralogical composition appears in table 1. At least three generations of alkali syenite have been distinguished at Kvanefjeld (Nielsen 1968), where they are confined to the southern and central part. Within the Ilimaussaq complex alkali syenite has only been found at Kvanefjeld and in the valley south of Kvanefjeld. Dykes and sills of similar composition have also been found in the southern part of the complex as well as in the Narssaq area to the west of Ilimaussaq (L. M. Larsen, personal communication).

The alkali syenite cuts the roof xenoliths and the augite syenite, and a fair chronology can be 
Table 1. The major rock types of the Kvanefjeld area.

\begin{tabular}{|c|c|c|c|c|}
\hline rock type & $\begin{array}{l}\text { texture } \\
\text { grain size }\end{array}$ & $\begin{array}{l}\text { essential } \\
\text { minerals }\end{array}$ & $\begin{array}{l}\text { accessory } \\
\text { minerals }\end{array}$ & \\
\hline anorthosite & $\begin{array}{l}\text { massive, } \\
\text { layered, } \\
\text { coarse }\end{array}$ & $\begin{array}{l}\text { plagioclase An50_60 } \\
\text { pyroxene }\end{array}$ & $\begin{array}{l}\text { iron oxide, } \\
\text { apatite }\end{array}$ & \\
\hline augite syenite & $\begin{array}{l}\text { massive, layered, } \\
\text { medium to coarse }\end{array}$ & $\begin{array}{l}\text { alkali feldspar, } \\
\text { ferrosalite } \\
\text { titanomagnetite } \\
\text { olivine }\end{array}$ & $\begin{array}{l}\text { biotite } \\
\text { apatite }\end{array}$ & \\
\hline alkali syenite & $\begin{array}{l}\text { massive, } \\
\text { fine to coarse }\end{array}$ & $\begin{array}{l}\text { microcline, } \\
\text { albite, } \\
\text { arfvedsonite, } \\
\text { aegirine }\end{array}$ & $\begin{array}{l}\text { neptunite, } \\
\text { pectolite }\end{array}$ & \\
\hline pulaskite & $\begin{array}{l}\text { massive, } \\
\text { coarse }\end{array}$ & $\begin{array}{l}\text { alkali feldspar, } \\
\text { alkali pyroxene, } \\
\text { alkali amphibole, } \\
\text { nepheline }\end{array}$ & $\begin{array}{l}\text { apatite, } \\
\text { fayalite, } \\
\text { magnetite, } \\
\text { sodalite } \\
\text { hedenbergite }\end{array}$ & \\
\hline $\begin{array}{l}\text { sodalite } \\
\text { foyaite }\end{array}$ & $\begin{array}{l}\text { massive, } \\
\text { coarse }\end{array}$ & $\begin{array}{l}\text { alkali feldspar, } \\
\text { nepheline, sodalite, } \\
\text { alkali pyroxene, } \\
\text { alkali amphibole }\end{array}$ & $\begin{array}{l}\text { eudualyte } \\
\text { apatite } \\
\text { fayalite } \\
\text { magnetite } \\
\text { hedenbergite }\end{array}$ & \\
\hline naujaite & $\begin{array}{l}\text { poikilitic, } \\
\text { coarse }\end{array}$ & $\begin{array}{l}\text { sodalite, nepheline, } \\
\text { alkali feldspar, } \\
\text { alkali pyroxene } \\
\text { alkali amphibole } \\
\text { eudialyte }\end{array}$ & $\begin{array}{l}\text { rinkite, } \\
\text { villiaumite } \\
\text { apatite } \\
\text { foyalite } \\
\text { magnetite } \\
\text { hedenbergite }\end{array}$ & \\
\hline lujavrite & $\begin{array}{l}\text { laminated, } \\
\text { fine }\end{array}$ & $\begin{array}{l}\text { microcline, } \\
\text { albite, nepheline, } \\
\text { arfvedsonite, } \\
\text { aegirine, } \\
\text { analcime }\end{array}$ & $\begin{array}{l}\text { eudialyte, } \\
\text { monazite, } \\
\text { lovozerite, } \\
\text { steenstrupine, } \\
\text { sphalerite, } \\
\text { Li-mica, } \\
\text { villiaumite }\end{array}$ & \\
\hline $\begin{array}{l}\text { lujavritic } \\
\text { pegmatite }\end{array}$ & $\begin{array}{l}\text { massive, } \\
\text { layered, } \\
\text { medium to coarse }\end{array}$ & $\begin{array}{l}\text { microcline, } \\
\text { albite, nepheline, } \\
\text { arfvedsonite, } \\
\text { aegirine, } \\
\text { analcime }\end{array}$ & $\begin{array}{l}\text { steenstrupine, } \\
\text { monazite } \\
\text { sphalerite }\end{array}$ & \\
\hline
\end{tabular}

Partly after Sørensen et al. (1969).

established among the alkali syenite generations. In contrast to the augite syenite the alkali syenite is peralkaline (Sørensen et al. 1969). It does not seem to have a direct genetic relation to either the augite syenite or the agpaitic series in contradiction to Hamilton (1964) who regarded the alkali syenite as an altered and chilled equivalent of the augite syenite. Unpublished data by L. M. 
Larsen suggest that the alkali syenite represents an external magma source possibly associated with trachytic and micro-granitic dykes in the Narssaq and Tugtutôq area.

One variety of the alkali syenite, in the field associated with the anorthosite, contains abundant plagioclase xenocrysts. The xenocrysts are usually altered into an aggregate of albite, nepheline, analcime and pectolite. The plagioclase xenocrysts have in all probability been derived from the anorthosite bodies, and the formation of this xenocrystic variety of alkali syenite is associated with the emplacement of the anorthosite into the alkali syenite. Although it is believed that the anorthosite xenoliths were derived from the roof, their origin and emplacement are not fully understood.

The alkali syenite has been intruded and veined by lujavrite and split into blocks separated by zones of lujavrite up to $50 \mathrm{~m}$ wide.

Pulaskite. The pulaskite is coarse-grained, grey, massive, typically with stumpy feldspar laths. Xenoliths of pulaskite occur only in the northern part of Kvanefjeld. In one large xenolith a transition from pulaskite to naujaite is exposed. The transition zone is 4 or $5 \mathrm{~m}$ thick and comprises layers of foyaite and sodalite foyaite in complete analogy with the transition from pulaskite to naujaite in the areas south and east of Taseq (fig. 1). Xenoliths derived from the rock units of this transition zone are common north of the Kvanefjeld summit and were seen embedded in lujavrite in drill cores collected east of the map (fig. 3).

Contact alteration in pulaskite xenoliths against lujavrite is insignificant.

Naujaite. The naujaite is a very coarse-grained agpaitic syenite with a conspicuous poikilitic texture formed by the enclosure of abundant crystals of sodalite in the other essential minerals alkali feldspar, arfvedsonite; aegirine, and eudialyte. In addition nepheline occurs. The rock has a crumbling weathering and appears whitish grey on weathered surfaces.

Xenoliths of naujaite are numerous at the surface and at depth in all parts of Kvanefjeld. The size of the inclusions ranges from about $100 \mathrm{~m}$ to a few centimetres across. They are rounded or angular in shape. Large xenoliths are characteri- stically surrounded by a number of small angular fragments which are undoubtedly derived from the large xenoliths.

The naujaite in the xenoliths has characteristic structures and textures in common with the naujaite around Taseq (Steenfelt 1972) which shows that they are derived from the upper part of the naujaite unit of the complex. The same conclusion has been reached by Steenfelt \& Bohse (1975), who used the uranium content of eudialyte as a correlation criterion.

In addition to xenoliths naujaite constitutes a marginal rim between the lujavrite and the country rock lavas to the north-west. This naujaite occurrence represents a pegmatite veined border facies of the agpaitic magma of intrusive phase III. A similar border facies is developed in the lower part of the complex, around the kakortokite, and it is believed that this kind of border development is characteristic of the evolved agpaitic magma which was enriched in volatiles. Hence the naujaitic border at Kvanefjeld is likely to represent a deeper part of the naujaite unit than the xenoliths. The position of xenoliths of pulaskite at the same altitude as the naujaitic border shows that these xenoliths have been displaced downwards.

In general the influence of the lujavritic magma on the naujaite is confined to the crystallisation of sodium- and niobium-rich minerals along pre-existing joints, but examples of assimilation of naujaite xenoliths are also found. The border facies naujaite has been metasomatised and assimilated along the contact with the lujavrite. The naujaite xenoliths are not deformed along the boundary with lujavrite.

\section{Mechanism of intrusion}

The generally applied mechanism of intrusion in the Gardar Province is one of permissive intrusion in combination with block subsidence (Upton 1960, 1962, Emeleus \& Harry 1970, Stephenson 1976). Many occurrences of subsided blocks have been described in the Gardar igneous complexes and, as reported by Ussing (1912), Hamilton (1964), Ferguson (1964) Sørensen (1970), Blaxland et al. (1976), the Ilimaussaq complex also provides several examples of blocks that have subsided from the walls or the roof into the 


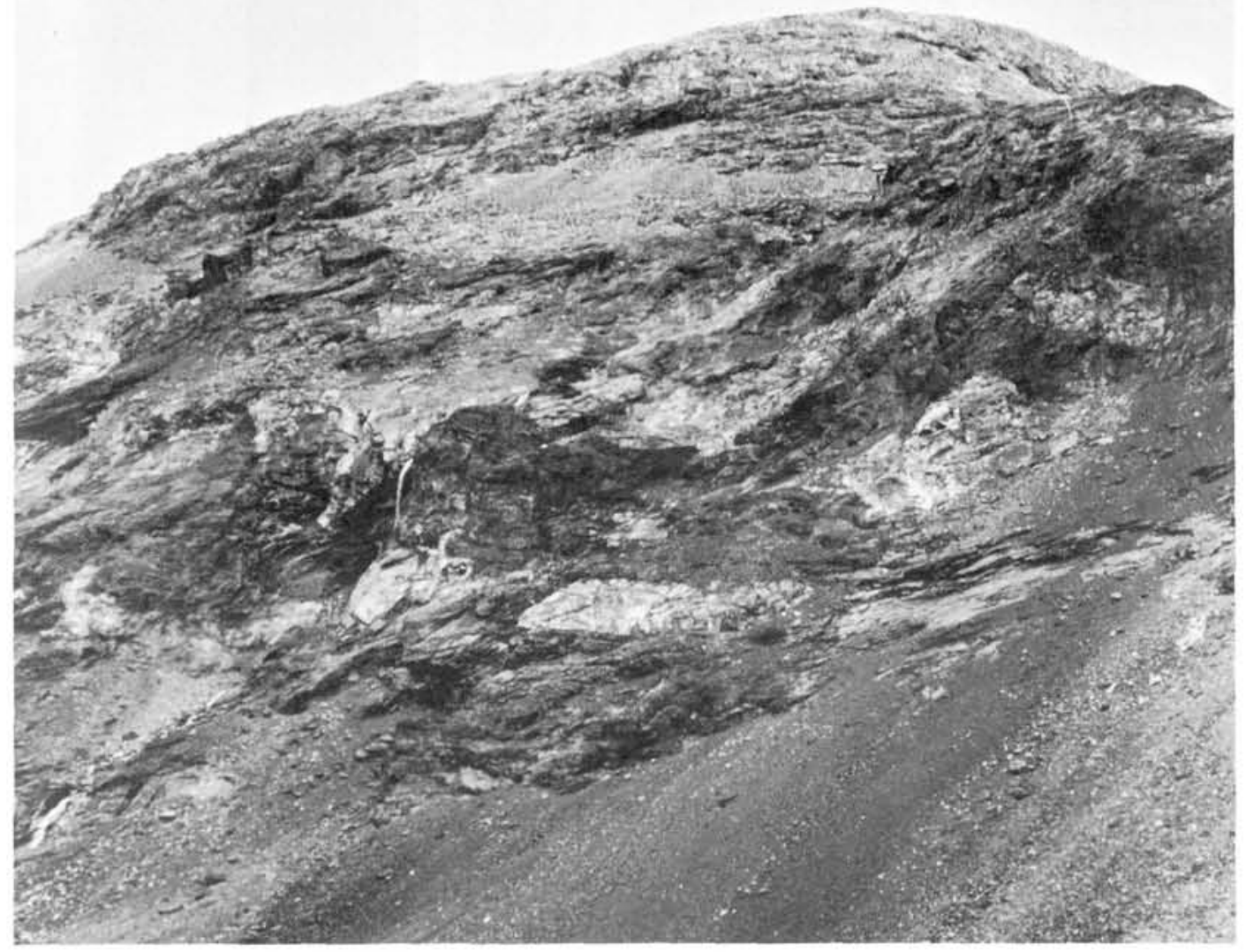

Fig. 6. Megaxenoliths of naujaite partly subsided into the underlying lujavrite. The locality is from the north coast of Tumugdliarfik. The size of the xenolith below the center of the picture is approximately $40 \times 10 \mathrm{~m}$.

magma at different stages in the evolution of the complex.

Xenoliths of sandstone and occasionally anorthosite and gabbro occur in the augite syenite. The pulaskite and foyaite south of Tunugdliarfik contain xenoliths of augite syenite, quartz syenite and alkali granite. Naujaite encloses a few small xenoliths of augite syenite and gabbro close to the contact with these rocks and large lumps of augite syenite and naujaite are embedded in kakortokite. The lujavrite as described encloses fragments of all other rock units of the complex as well as of country rocks. These xenolith occurrences indicate that block subsidence accompanied each of the intrusive phases at Ilimaussaq. Naujaite xenoliths in lujavrite are shown in fig. 6 .

At Kvanefjeld the xenoliths of the Eriksfjord
Formation, the gabbro, and the pulaskite were shown to have subsided to their present position. In spite of the very low specific gravity of naujaite (2.55, Ussing 1912) naujaite xenoliths, as mentioned earlier, are also believed to have sunk in the lujavritic magma which was composed of a very light liquid phase rich in alkalis and volatiles carrying the cumulus minerals alkali feldspar and aegirine in suspension. The naujaite xenoliths in the kakortokite (fig. 1) demonstrate that naujaite did in fact subside in the magma above the kakortokite which must have been close in composition and temperature to the lujavritic magma.

When the lujavritic magma ascended from a level below the naujaite into the Kvanefjeld area it largely followed the regional NE-SW structures. This feature and the evidence for subsidence 
of blocks into the lujavritic magma is taken by the authors to indicate that permissive intrusion by faulting and subsidence of roof blocks also applied to the emplacement of the lujavrites.

\section{The Kvanefjeld area prior to the lujavrite intrusion}

Whereas the xenoliths in the northern and western part of Kvanefjeld have subsided to their present position, the small proportion of lujavrite relative to xenoliths in the southern part of Kvanefjeld, and the coherent character of the augite syenite suggest that brecciation with subsequent lujavrite veining predominated, and that the pre-lujavritic rock units in this area are more or less in situ. With these assumptions the pre-lujavritic events at Kvanefjeld are reconstructed.

The first intrusive event in the Kvanefjeld area was the ascent of the augite syenitic magma. As no inclusions of augite syenite are found in the northern part of Kvanefjeld either at the surface or at depth; the boundary for the augite syenite magma is assumed to be close to the northern limit of the augite syenite inclusions.

The alkali syenite was injected by consecutive pulses. It intruded the augite syenite and possibly the country rocks above so as to engulf blocks of anorthosite that were loosened from the roof. The volume of alkali syenitic magma was small.

The agpaitic magma exceeded the extent of the augite syenite and alkali syenite enclosing them as a sheath or raft and consolidated against the lavas. Against the roof the normal sequence of pulaskite, foyaite, and sodalite foyait was developed.

Stewart (1964) suggested that the remnants of volcanic roof north-east of Taseq (fig: 1 ) had subsided $300-400 \mathrm{~m}$. The pulaskite near Taseq is situated about $300 \mathrm{~m}$ above the pulaskite xenoliths at Kvanefjeld. It is therefore tentatively assumed that the present level of exposure before the lujavrite intrusion was situated at least $300 \mathrm{~m}$ below the roof. As mentioned earlier this assumption is supported by the presence of pegmatites in the border facies of the naujaite.

The mobilisation of the lujavritic magma most likely happened in connection with a major event of subsidence (Sørensen 1970). At the marginally situated Kvanefjeld area this resulted in faulting and brecciation in a NE-SW zone bounded to the south-east by naujaite with augite syenite rafts, and to the north and north-west by the naujaitic border or by country rocks.

\section{The origin of the deformation zones in the country rock xenoliths}

The large xenoliths of the Eriksfjord Formation are partly rounded and deformed along their margins as described in the chapter on country rocks. The degree of deformation varies and ultimately plastic deformation has occurred. By contrast the xenoliths of naujaite have generally sharp contacts with the lujavrite, and they are not deformed along their margins. The augite syenite and alkali syenite blocks are occasionally deformed.

If the deformation of the margins is ascribed mainly to the intrusion of lujavrite, as assumed by Sørensen et al. (1969), a similar or stronger deformation of the naujaite margins would certainly be expected as the melting temperature of naujaite (Piotrowski \& Edgar 1970, Sood \& Edgar 1970 ) is much lower than the melting temperature of a basaltic rock. In addition it seems that the lujavrite at Kvanefjeld was less reactive (i.e. colder) towards naujaite inclusions than the lujavrite at deeper levels e.g. at the head of Kangerdlusarssuk where assimilation of naujaite is a widespread phenomenon. At a few places found in drill cores sheared lavas are in contact with naujaite, indicating that some deformation has occurred before the lujavrite intrusion.

"Consequently a longer history for the formation of the deformed margins is suggested. Initially shear zones were formed in the Eriksfjord Formation in response to regional tectonic movements prior to or contemporaneously with the intrusion of the augite syenite. The intrusion of the acid magma (phase II) may or may not have affected the area around Kvanefjeld. Block faulting and accentuation of existing shear zones occurred when the agpaitic magma (phase III) intruded. Much of the heat conveyed by the agpaitic magma was conducted through the roof. Existing shear zones were softened by the heat and altered chemically. As the shear zones were zones of weakness they partly controlled the outer form of the blocks during the final collapse of 
the roof. The ultimate deformation was achieved when the preheated roof blocks sank into the lujavritic magma, and heavy metasomatism and niobium mineralisation took place.

By analogy the deformed margins of the anorthosite bodies can be explained by preheating, deformation, and alteration at the time when the anorthosite was subjected to the alkali syenitic magma and subsequent additional deformation and mineralisation by the lujavritic magma.

Although the rather passively (in contrast to forcefully) injected lujavritic magma of low temperature and viscosity is not generally regarded as the source of the heat which produced the plastic deformation of the country rock xenoliths, an important exception is found in the medium- to coarse-grained or pegmatitic lujavrite which represents the latest stage of the cooling history of the lujavritic magma. Basalt and gabbro in contact with this aggressive melt were heavily metasomatised and extensively assimilated whereby a zone of mixed rock was produced. Mineralisation with uranium and thorium is associated with the zone of mixed rock.

\section{Summary of principal events at Kvanefjeld}

1. Faulting and shearing of the Eriksfjord Formation in response to regional tectonic movements.

2. Intrusion of augite syenitic magma.

3. Intrusion of alkali syenitic magma.

4. Intrusion of agpaitic magma to form a stratified sequence of pulaskite, foyaite and naujaite. Augite syenite engulfed by naujaite. Subsidence of fragments of the roof.

5. Intrusion of the lujavritic magma accompanied by the roof collapse with subsequent fragmentation and subsidence of blocks.

6. Hydrothermal veins.

\section{Conclusion}

The complex geology of Kvanefjeld is explained as a result of its marginal position in an igneous complex where repeated intrusions of magma were permitted by faulting and subsidence of blocks from the walls and roof into the magmas.
Acknowledgement. This paper is published with the permission of the Director of the Geological Survey of Greenland.

\section{Dansk sammendrag}

Kvanefjelds geologi er af stor interesse dels på grund af dens betydning for forståelsen af límaussaq kompleksets geologiske historie, dels på grund af de udbredte uranmineraliseringer $i$ området. Kvanefjeld består hovedsagelig af lujavrit, hvori indeslutninger af xldre bjergarter befinder sig. Indeslutningerne stammer fra Eriksfjord Formationens bjergarter (lava, sandsten og gabbro) samt fra Ilimaussaq-kompleksets aldre syenitter (augit-syenit, pulaskit og naujait). Under hovedfasen af lujavritintrusionen er det overliggende tag styrtet sammen, og de løsrevne blokke er sunket ned i lujavritmagmaet. På basis af korrelationer med lignende bjergarter uden for Kvanefjeldsområdet foreslås det, at Ilimaussaq kompleksets tag på dette sted har ligget ca. $300 \mathrm{~m}$ over det nuværende erosionsniveau.

Et mere sammenhængende område af augitsyenit i den sydlige del af Kvanefjeld formodes at vare delvis in situ og at repræsentere den nordligste grænse af den intruderede augitsyenit. Augitsyenitten er $i$ smalle zoner intruderet af lujavrit. Naujaitten intruderede til et højere niveau end augitsyenitten ligesom gransen mod Eriksfjord Formationen ligger langere mod nord. Naujaitpegmatit danner i overensstemmelse hermed Ilimaussaq kompleksets nordvestligste grænse.

Mange af blokkene fra intrusionens tag er udvalsede og niobiummineraliserede $\mathrm{i}$ randzonen, hvilket ikke er tilfældet med f.eks. naujaitblokkene. Denne forskel antages at bero på en langvarig varmepåvirkning og pneumatolytisk omdannelse $i$ udvalsningszoner $i$ taget. Da taget styrtede sammen, foregik dette $i$ vid udstrakning langs de $i$ forvejen blødgjorte zoner, således at den endelige udvalsning kunne finde sted under nedsynkningen i lujavritmagmaet.

\section{References}

Blaxland, A. B., Van Breemen, O. \& Steenfelt, A. 1976: Age and origin of agpaitic magmatism at Ilimaussaq. South Greenland: Rb-Sr study. Lithos 9, 31-38.

Blaxland, A. B., Van Bremen, O., Emeleus, C. H. \& Anderson, J. G. 1978: Age and origin of the major syenite centers in the Gardar province of South Greenland: Rb-Sr studies. Geol. Soc. Am. Bull. 89, 231-244.

Bridgwater, D. \& Harry, W.T. 1968: Anothosite xenoliths and plagioclase megacrysts in Precambrian intrusions in South Greenland. Bull. Gronlands geol. Unders. 77 (also Meddr Grønland 185, 2), $243 \mathrm{pp}$.

Emeleus, C. H. \& Harry, W. T. 1978: The Igaliko nepheline syenite complex. General description. Bull. Grønlands geol. Unders. 85 (also Meddr Gronland 186, 3), $116 \mathrm{pp}$.

Emeleus, C. H. \& Upton, B. G. J. 1976: The Gardar period in southern Greenland. In: Escher, A. \& Watt, W. S. (eds). Geology of Greenland 153-180. Copenhagen: Gcological Survey of Greenland.

Engell, J. 1973: A closed system crystal-fractionation model for the agpaitic Ilimaussaq intrusion, South Greenland with special reference to the lujavrites. Bull. Geol. Soc. Denmark, 22, 334-362.

Ferguson, J. 1964: Geology of the Ilimaussaq alkaline intrusion, South Greenland. Bull. Gronlands geol. Unders. 39, (also Meddr Gronland 172, 4) 82 pp.

Ferguson, J. 1970: The significance of the kakortokite in the evolution of the Ilimaussaq intrusion. South Greenland. Bull. Gronlands geol. Unders. 89 (also Meddr Gronland 190, 1), 193 pp. 
Hamilton, E. I. 1964: The geochemistry of the northern part of the Ilimaussaq intrusion, S. W. Greenland. Bull. Grønlands geol. Unders. 42 (also Meddr Grønland 162, 10), $104 \mathrm{pp}$.

Hansen, J. 1968: Niobium mineralization in the Ilimaussaq alkaline complex, South-West Greenland. Rep. 23rd int. geol. Congr., Praha, 7, 263-273.

Larsen, J. G. 1974: Stratigrafi, geokemi og petrologi $i$ den øvre vulkanske del af Eriksfjord Formationen, Gardarprovinsen, Sydgronland. Unpublished dissertation, Univ. Copenhagen, also GGU internal report, $134 \mathrm{pp}$.

Larsen, J. G. 1977: Petrology of the late lavas of the Eriksfjord Formation, Gardar province, South Greenland. Bull. Geol. Soc. Denmark 125, 31 pp.

Larsen, L. M. 1976: Clinopyroxenes and coexisting mafic minerals from the alkaline Ilimaussaq intrusion, South Greenland. J. Petrol. 17, 258-290.

Nielsen, B. L. 1968: Anorthositforekomsterne på Kvanefjeld. Unpublished dissertation, Univ. Copenhagen, also GGU internal report, $127 \mathrm{pp}$.

Nyegaard, P., Nielsen, B. L., Lovborg, L. \& Sørensen, P. 1977: Kvanefjeld Uranium project. Drilling programme 1977. GGU internal report.

Patchett, P. J., Hutchinson, J., Blaxland, A. B. \& Upton, B. G. J. 1978: Origin of anorthosites, gabbros and potassic ultramafic rocks from the Gardar Province, South Greenland: Sr isotopic ratio studies. Bull. Geol. Soc. Denmark $25,79-84$.

Piotrowski, J. M. \& Edgar, A. D. 1970: Melting relations of undersaturated alkaline rocks from South Greenland. Meddr Gronland 181, 9, 62 pp.

Poulsen, V. 1964: The sandstones of the Precambrian Eriksfjord Formation in South Greenland. Rapp. Gronlands geol. Unders. 2, $16 \mathrm{pp}$.

Sood, M. K. \& Edgar, A. D. 1970: Melting relations of undersaturated alkaline rocks. Meddr Grønland 181, 12, 41 pp.

Sørensen, H. 1958: The Ilimaussaq batholith. A review and discussion. Bull. Gronlands geol. Unders 19 (also Meddr Grenland 162, 3), $48 \mathrm{pp}$.

Sørensen, H. 1970: Internal structures and geological setting of the three agpaitic intrusions - Khibina and Lovozero of the Kola Peninsula and Ilimaussaq, South Greenland. Can. Miner. 10, 299-334.

Sorensen, H. 1978: The position of the augite syenite and pulaskite in the Ilimaussaq intrusion, South Greenland. Bull. Geol. Soc. Denmark 27, special issue, 15-23.

Sørensen, H., Hansen, J \& Bondesen, E. 1969: Preliminary account of the geology of the Kvanefjeld area of the Ilimaussaq intrusion, South Greenland. Rapp. Grønlands geol. Unders. $18,40 \mathrm{pp}$.

Sørensen, H., Rose-Hansen, J. Nielsen, B. L., Løvborg, L. Sørensen, E. \& Lundgaard, T. 1974: The uranium deposit at Kvanefjeld, the Ilimaussaq intrusion, South Greenland. Rapp. Grønlands geol. Unders. 60, $54 \mathrm{pp}$.

Steenfelt, A. 1972: Beskrivelse af pulaskit, heterogen foyait, sodalit-foyait, naujait og kakortokit pd Kvanefjeldsplateauet, Ilimaussaq. Unpublished dissertation, Univ. Copenhagen, also GGU internal report, $58 \mathrm{pp}$.

Steenfelt, A \& Bohse, H. 1975: Variations in the content of uranium in eudialyte from the differentiated alkaline Ilimaussaq intrusion, South Greenland. Lithos 8, 39-45.

Stephenson, D. 1976: A simple-shear model for the ductile deformation of high-level intrusions in South Greenland. J. Geol. Soc. London 132, 307-318.

Stewart, J. W. 1964: The earlier Gardar igneous rocks of the Ilimaussaq area, South Greenland. Unpublished Ph.D. Thesis, Univ. Durham, England, 423 pp.

Upton, B. G. J. 1960: The alkaline igneous complex of Kûngnât Fjeld, South Greenland. Bull. Grønlands geol. Unders. 27 (also Meddr Gronland 123, 4), 145 pp.

Upton, B. G. J. 1962: Geology of Tugtutôq and neighbouring islands, South Greenland. I. Bull. Grønlands geol. Unders. 34 (also Meddr Grønland 169, 8), 60 pp.

Upton, B. G. J. 1971: Meltirig experiments on chilled gabbro and syenogabbros. Carnegie Inst. Wash. Year Book 70, 112-118.

Ussing, N. V. 1912: Geology of the country around Julianehaab, Greenland. Meddr Grønland 38, $376 \mathrm{pp}$.

Van Breemen, O., Aftalion, M. \& Allaart, J. H. 1974: Isotopic and geochronologic studies on granites from the Ketilidian mobile belt of South Greenland. Bull. geol. Soc. Amer. 85, $403-412$ 